\title{
Phenotypic and genotypic diversity of Xanthomonas axonopodis pv. manihotis causing bacterial blight disease of cassava in Kenya
}

\author{
Mary N. Chege ${ }^{1,2}$, Fred Wamunyokoli ${ }^{2}$, Joseph Kamau $^{1}$, Evans N. Nyaboga ${ }^{1 *}$ \\ ${ }^{1}$ Department of Biochemistry, University of Nairobi, P.O Box 30197 - 00100, Nairobi, Kenya. \\ ${ }^{2}$ Department of Biochemistry, Jomo Kenyatta University of Agriculture and Technology, P.O Box 62000 - 00200, Nairobi, Kenya.
}

\begin{tabular}{l} 
ARTICLE INFO \\
\hline Article history: \\
Received on: $17 / 11 / 2016$ \\
Accepted on: $20 / 12 / 2016$ \\
Available online: $20 / 03 / 2017$ \\
\hline Key words: \\
Cassava bacteria blight, \\
Xanthomonas axonopodis pv. \\
manihotis, phenotypic \\
characteristics, genetic diversity.
\end{tabular}

\begin{abstract}
Cassava bacterial blight (CBB), caused by Xanthomonas axonopodis pv. manihotis (Xam), is the most important bacterial disease of cassava. There is no information available on the morphological and genetic variability of Xam isolates from Kenya. The aim of this study therefore, was to determine the diversity of Xam isolates from different cassava growing regions of Kenya using phenotypic characteristics and repetitive DNA polymerase chain reaction-based fingerprinting (rep-PCR). Thirty three isolates were recovered from infected cassava leaf samples collected from farmers' fields in cassava growing regions. The dendrogram generated from analysis of phenotypic characteristics of the isolates produced two major clusters at $75 \%$ similarity level. Analysis of 19 isolates with repetitive extragenic palindromic (rep) primers yielded characteristic fingerprint pattern with bands ranging between 400 and 2000 bp in size and their numbers ranged from 1 to 6 bands per isolate. Cluster analysis using unweighted pair group method with arithmetic averages (UPGMA) did not reveal any significant differences in clustering and relationship to the geographical origin, with exception of a single isolate that had unique fingerprints. These findings indicate that Xam population in Kenya evolved from the same origin and is a uniform population, and this may prove useful in future breeding programmes.
\end{abstract}

\section{INTRODUCTION}

Cassava (Manihot esculenta Crantz) is an important source of food and income to more than 300 million people in sub-Saharan Africa. Its tuberous roots accumulate starch (approximately $30-60 \%$ dry matter) and it is considered the second source of starch globally, after maize [1]. In Kenya, cassava is the third most important food crop and its tuberous roots provide over a quarter of the daily calorie consumption. The leaves are consumed as a vegetable, providing an important source of proteins, vitamins and micronutrients. Cassava is drought tolerant and can be grown in marginal soils, typical of low-income, small-scale farmers, with minimum inputs. However, production of cassava is limited by viral, bacterial, fungal, phytoplasmas and insect-pest attacks on tuberous roots and plants. The most important disease that can cause high losses to subsistence farmers in Kenya is cassava bacterial

* Corresponding Author

Evans Nyaega Nyaboga, Department of Biochemistry,

University of Nairobi, P.O Box 30197 - 00100, Nairobi, Kenya.

Email:nyaboga@uonbi.ac.ke blight (CBB). Cassava bacterial blight (CBB) disease caused by Xanthomonas axopodis pv. manihotis (Xam) is a major disease of cassava across sub-Saharan Africa and South America. It is a vascular disease that reduces the production of cassava up to $100 \%$ since it affects both planting material and yields [2, 3]. Diverse symptoms are displayed by CBB infected cassava plants including wilting of leaves, blighting, formation of angular leaf lesions, stem cankers, stem and leaf exudates production and, dieback of stems. Infection of $\mathrm{CBB}$ commences with the multiplication of Xam in the leaves around the stomata and eventually enters into vascular system through the stomatal pores [4]. The entry of Xam into the vascular system triggers defense-response, which include suberin deposition, lignin deposition, accumulation of phenolic compounds, and occlusion of vessels. The degree of the impact of CBB varies depending on the population of pathogens, their pathogenicity, and genotypes of cassava [5]. The control measures for CBB include use of clean propagative cuttings, crop rotation, planting towards the end of the rainy season and removal of infected material. However, none of these control measures have been found effective against CBB. These methods are aimed at reducing bacterial populations in the field [6]. 
As with most plant bacterial diseases, the use of resistant varieties would be the most effective method of managing CBB. However, development of disease-resistant varieties through conventional breeding requires resistant donor parents. The development and deployment of cultivars with durable resistance to $\mathrm{CBB}$ necessitates a detailed understanding of the diversity of pathogen populations. Variation of pathogen populations can relate to differences in pathogenicity and/or virulence of isolates of the same pathogen [7], and such differences can be attributed to differences in genetic makeup of the bacterial isolates. Therefore, for effective control of CBB, understanding the genetic variation of pathogen populations in different regions is important for breeding because plants need to have resistance against all pathogenic strains. In addition, in order to develop efficient disease management strategies, the genetic diversity of the pathogens population under the climatic conditions studied must be known since genetic diversity of Xam has been reported to be directly correlated with environmental conditions [8]. If the genetic variation of the pathogen is not considered in the different cassava growing regions, it may lead to an increase or decrease in the virulence which might in turn lead to susceptibility in cultivars that were previously resistant to the pathogen [9].

Phenotypic characterization is an important first step in the assessment of diversity of pathogenic bacteria; however it is time consuming and is highly error prone due to morphological plasticity, which is influenced by environmental conditions. Therefore, pathogen diversity can be augmented by combining both genotypic differences between strains and phenotypic analyses. A number of PCR based methods have been used for identification and genetic characterization of Xam isolates including use of random amplified polymorphic DNA (RAPDs) [10], restriction fragment length polymorphism (RFLPs) [11], amplified fragment length polymorphisms (AFLP) [12] and repetitive extragenic palindromic-polymerase chain reaction (repPCR). Repetitive extragenic palindromic PCR technique has been shown to be simple and fast and thus useful for studying plant pathogen population structures [13, 14]. It has been used successfully for characterizing xanthomonads and pseudomonads $[13,14]$. Therefore, rep-PCR is strongly recommended for genetic characterization of pathogenic bacteria because it is more precise in terms of identification and evaluation of diversity [15].

To date, no information is available regarding the phenotypic or genetic variability of Xam populations from cassava growing regions in Kenya. Therefore, the objectives of this study were to identify phenotypic and genetic variability of Xam isolates collected from different cassava growing regions of Kenya.

\section{MATERIALS AND METHODS}

\subsection{Collection of infected cassava samples}

Leaf samples were collected from cassava plants showing bacterial blight symptoms from five cassava growing regions (Western, Coastal, Nyanza, Central and Eastern) of Kenya (Figure 1). A total of 33 cassava leaf samples were randomly collected from farmers fields (Table 1). More samples were collected from Western (18) and Coastal regions, (8) which are the main cassava growing regions followed by Nyanza (5), Eastern (1) and Central (1). The samples were collected in sterile polythene bags containing silica gel, transferred to the laboratory at the Department of Biochemistry, University of Nairobi and stored at room temperature for subsequent Xam isolation and characterization.

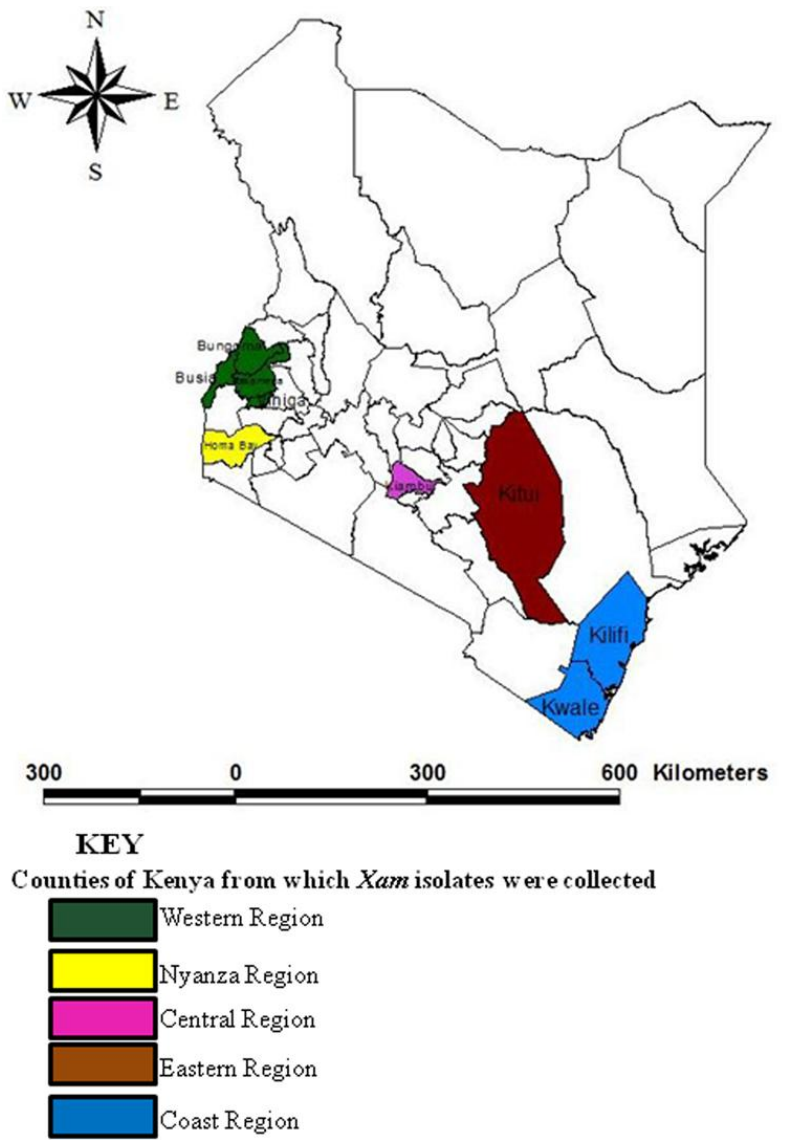

Fig. 1: Map of Kenya showing Counties from which Xam isolates used in this study were collected.

Table 1: Summary of the origin of X. axonopodis pv. manihotis isolates used in this study

\begin{tabular}{|c|c|c|c|}
\hline Region & County & $\begin{array}{l}\text { Number of isolates per County } \\
\text { and their ID code }\end{array}$ & $\begin{array}{l}\text { Number of } \\
\text { isolates per } \\
\text { region }\end{array}$ \\
\hline \multirow{4}{*}{ Western } & Kakamega & $\begin{array}{c}7 \text { (Xam1-W, Xam2-W, Xam3-W, } \\
\text { Xam4-W, Xam5-W, Xam6-W } \\
\text { and Xam18-W) }\end{array}$ & \multirow{4}{*}{18} \\
\hline & Vihiga & $\begin{array}{c}5 \text { (Xam7-W, Xam8-W, Xam9-W, } \\
\text { Xam10-W and Xam11-W) }\end{array}$ & \\
\hline & Bungoma & 2 (Xam12-W and Xam13-W) & \\
\hline & Busia & $\begin{array}{l}4 \text { (Xam14-W, Xam15-W, } \\
\text { Xam16-W and Xam17-W) }\end{array}$ & \\
\hline Eastern & Kitui & 1 (Xam19-E) & 1 \\
\hline Nyanza & Homabay & $\begin{array}{c}4 \text { (Xam20-N, Xam21-N, Xam22- } \\
\text { N, Xam23-N and Xam24-N) }\end{array}$ & 5 \\
\hline Central & Kiambu & $1(\mathrm{Xam} 25-\mathrm{Ce})$ & 1 \\
\hline \multirow[t]{2}{*}{ Coast } & Kilifi & $\begin{array}{c}6 \text { (Xam26-C, Xam27-C, Xam28- } \\
\text { C, Xam29-C, Xam30-C and } \\
\text { Xam31-C) }\end{array}$ & \multirow[t]{2}{*}{8} \\
\hline & Kwale & $2(\mathrm{Xam} 32-\mathrm{C}$ and Xam33-C) & \\
\hline
\end{tabular}




\subsection{Isolation of bacteria}

Isolation of the pathogen was done as described by Verdier et al. [16] and Ogunjubi and Fagade [17]. Leaf tissues were macerated into small pieces of about $2 \mathrm{~mm}^{2}$ and transferred into sterile $15 \mathrm{ml}$ falcon tubes. About $5 \mathrm{ml}$ YPG-CC (yeast extract (1\%), peptone $(1 \%)$, glucose $(1 \%)$, agar, cephalexin $\left(50 \mathrm{mg} \mathrm{l}^{-1}\right)$ and cycloheximide $\left(150 \mathrm{mg} \mathrm{l}^{-1}\right), \mathrm{pH}$ 7.0.) liquid selective media was added and incubated for 48 hours at $28{ }^{\circ} \mathrm{C}$. The bacterium suspension was diluted serially to $10^{-3}$, and aliquots of $0.1 \mathrm{ml}$ of each of the 10-fold dilution samples transferred onto YPGA-CC medium (yeast extract (1\%), peptone $(1 \%)$, glucose $(1 \%)$, agar (1.5\%), pH 7.0) supplemented with cephalexin (50 $\mathrm{mg} \mathrm{l}^{-1}$ ) and cycloheximide $\left(150 \mathrm{mg} \mathrm{l}^{-1}\right)$.

The Petri dishes were incubated at $28{ }^{\circ} \mathrm{C}$ for 48 hours. Single colonies were selected and purified by re-streaking on YPGA-CC, grown at $28{ }^{\circ} \mathrm{C}$ for 48 hours and kept at $-20{ }^{\circ} \mathrm{C}$ for storage in $30 \%$ glycerol.

\subsection{Identification of Xam isolates}

Identification of bacterial isolates was carried out using both the Gram staining reaction and 3\% KOH test. Gram staining reaction was done as described by Bradbury [18]. Gram staining reaction was confirmed by performing 3\% $\mathrm{KOH}$ test. Pure bacterial colony was taken with a toothpick and vigorously stirred in one drop of $3 \% \mathrm{KOH}$ solution.

After mixing, a tooth pick was raised a few centimetres from a glass slide to observe a strand of viscid mucous material as described by Gregersen [19]. If strands of viscid material were observed, the bacterial isolates were regarded as Gram-negative. Lack of strands of viscid material was recorded as Gram-positive.

\subsection{Phenotypic characterization of $\mathrm{Xam}$ isolates}

Bacterial suspensions of each isolate were streaked onto plates of YPGA-CC selective media. The plates were incubated at $28{ }^{\circ} \mathrm{C}$ for 48 hours followed by morphological characterization. All the isolates were observed on YPGA-CC plates for colony color, form, elevation, size, surface, edges, structures, growth rate of colonies and colony texture as described by Bradbury [20] and Fahy et al. [21].

\subsection{Molecular characterization of Xam isolates}

Out of the $26 \mathrm{Xam}$ isolates recovered, 19 were selected based on hierarchical cluster analysis from morphological characterization for further genetic diversity studies.

\subsubsection{DNA isolation}

Extraction of genomic DNA from cultures of bacterial isolates was performed using DNeasy ${ }^{\circledR}$ mini kit (Qiagen, 2013) following manufacturer's instructions. The DNA was resuspended in sterile double distilled water. DNA integrity and quality were checked by agarose gel electrophoresis in $1 \mathrm{X}$ Tris-acetate-EDTA
(TAE) and quantified using a spectrophotometer (Beck Man Coulter UV/VIS, USA)

\subsubsection{Detection of Xam using PCR}

The DNA extracted from cultures of bacterial isolates was subjected to PCR analysis using Xam-specific primers $\mathrm{XV}$ (5'-TTC-GGC-AAC-GGC-AGT-GAC-CAC-C-3') and XK (5'TCA-ATC-GGA-GAT-TAC-CTG-AGG-G-3') in a MJ Mini $^{\text {TM }}$ personal Thermal Cycler (BIO-RAD, Singapore). PCR reactions were performed in a total volume of $20 \mu \mathrm{l}$ thin-walled Accupower ${ }^{\mathrm{TM}}$ PCR tube (USA Bioneer, Inc.) using $1 \mu \mathrm{l}$ of $1.5 \mathrm{mM}$ $\mathrm{MgCl}_{2}, 4 \mu \mathrm{l}$ of buffer $5 \mathrm{X}, 0.5 \mu \mathrm{l}$ of $0.5 \mathrm{mM} \mathrm{dNTPs}, 0.5 \mu \mathrm{l}$ of 10 $\mu \mathrm{M}$ of each primer, $0.5 \mu \mathrm{l}$ of 1.25 units of Taq polymerase, $2 \mu \mathrm{l}$ of $25 \mathrm{ng} / \mu \mathrm{l}$ of DNA and $11.5 \mu \mathrm{l}$ of sterile double-distilled water. The PCR cycling conditions were an initial denaturation at $95{ }^{\circ} \mathrm{C}$ for 2 minutes followed by 30 cycles of $94{ }^{\circ} \mathrm{C}$ for 30 seconds (denaturation), $55^{\circ} \mathrm{C}$ of 1 minute (annealing) and $72{ }^{\circ} \mathrm{C}$ for 1 minute (extension) and a final extension of 5 minutes. The PCR products were electrophoresed on a $1 \%(\mathrm{w} / \mathrm{v})$ agarose gel in $1 \mathrm{X}$ TAE buffer containing $0.5 \mu \mathrm{g} / \mathrm{ml}$ of Gel Red and visualized in a UV transilluminator.

\subsubsection{Repetitive elements based PCR (rep-PCR)}

A total of $19 \mathrm{Xam}$ isolates were analyzed. Amplification reactions were performed using primer pair: REP1R-2 (5'IIIICGICGICATCIGGC -3') and REP2-2 (5'ICGICTTATCIGGCCTAC -3') as described by Louws et al. [22]. PCR amplifications were carried out in a $25 \mu$ l reaction volume consisting of $4 \mu \mathrm{l}$ of $10 \mathrm{X}$ PCR buffer, $0.5 \mu \mathrm{l}$ of each primer, $0.2 \mu \mathrm{l}$ of Taq DNA polymerase (Qiagen), $0.5 \mu \mathrm{l}$ of dNTPs, $1 \mu \mathrm{l}$ of $\mathrm{MgCl}_{2}, 16.3 \mu \mathrm{l}$ of double-distilled water and $2 \mu \mathrm{l}(50 \mathrm{ng} / \mu \mathrm{l})$ of bacterial DNA. A non-template reaction was included as a negative control. PCR reactions were performed in a MJ Mini ${ }^{\mathrm{TM}}$ personal Thermal Cycler (BIO-RAD, Singapore) using the following conditions: initial denaturation at $95{ }^{\circ} \mathrm{C}$ for 7 minutes, followed by 30 cycles of $94{ }^{\circ} \mathrm{C}$ for 1 minute (denaturation), $44{ }^{\circ} \mathrm{C}$ for 1 minute (annealing) and $65^{\circ} \mathrm{C}$ for 8 minutes (extension) with a final extension at $65{ }^{\circ} \mathrm{C}$ for 15 minutes. The PCR products were electrophoresed on a $1.5 \%(\mathrm{w} / \mathrm{v})$ agarose gel in $1 \mathrm{X}$ TAE buffer containing $0.5 \mu \mathrm{g} / \mathrm{ml}$ of GelRed and visualized in a UV transilluminator. All PCR reactions were repeated at least three times for each sample to verify the consistency of the patterns. Genomic fingerprint comparisons among Xam isolates were performed by measurement of band sizes. Only clear and reproducible bands were scored for each Xam isolate. Bands generated by the rep-PCR analysis were converted into a twodimensional binary matrix ( 1 , presence; and 0 , absence of a band) using Jaccard ( $\mathrm{J})$ coefficient, which do not consider the negative similarities.

The matrix was analyzed by Popgene package. Unweighted Pair Group Method with Arithmetic mean (UPGMA) algorithm was used to perform hierarchical cluster analysis and construct a dendrogram. 


\section{RESULTS AND DISCUSSION}

\subsection{Isolation and identification of Xam isolates}

A total of 26 bacterial isolates were recovered from 33 cassava infected samples. The bacterial isolates produced large mucoidal colonies on YPGA-CC selective media (Figure 2). Biochemical tests of the bacterial isolates indicated that all the isolates were Gram-negative and produced mucoidal thread-like rods in $3 \% \mathrm{KOH}$ (Figure 2).
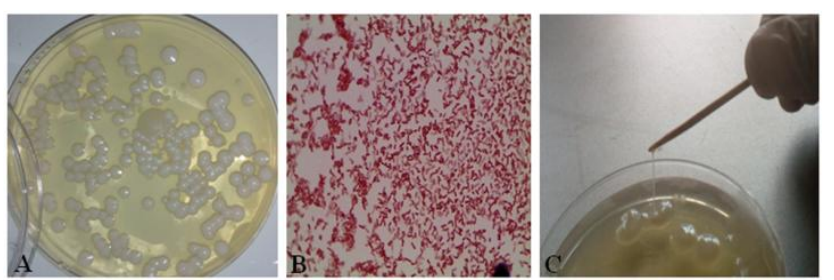

Fig. 2: Colonies of Xam isolated from infected leaf samples and results of biochemical tests. (A) colony of Xam on YPGA-CC; (B) mucous thread produced by Gram-negative bacteria on $3 \% \mathrm{KOH}$; and (C) microscopic view of Gram stained Xam isolate.

\subsection{Phenotypic characterization}

Colonies of cultured Xam isolates appeared after 48 hours on YPGA-CC selective media. The colonies of the isolates were white/cream/yellow, mucoid and circular/round on YPGACC (Figure 2). Colony color varied from white to cream in all the isolates except one isolate (Xam12-W) that was yellow (Figure 3). These observations confirm reports by Verdier et al. [23] who found that Xam colonies appear creamy and whitish in color and form distinct isolated colonies. In addition, Trujillo et al. [24] reported that Xam cultured on selective media is distinguished by white and cream colonies. Reports of variations in color, shape, elevation and contour (margin) among Xam strains have also been documented in previous studies [25, 26, 27].

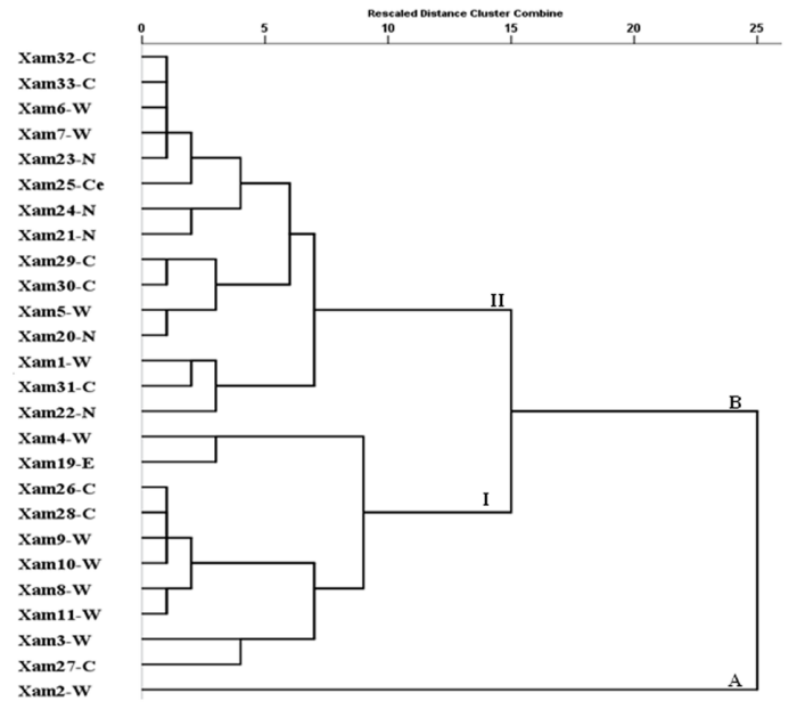

Fig. 3: Colonies of Xam after 48 hours of culture on YPGA-CC selective media showing the distinguishing features of Xam. (A) Xam1-W; (B) Xam12-W; (C) Xam21-N and (D) Xam25-C.

Phylogenetic analysis of the $26 \mathrm{Xam}$ isolates resulted in two major clusters A and B. Cluster A contained only one isolate,
Xam 2-W, obtained from western Kenya. Cluster B was further sub-divided into 2 sub-clusters. Sub-cluster I comprised ten isolates (Xam4-W, Xam19-E, Xam26-C, Xam28-C, Xam9-W, Xam10-W, Xam8-W, Xam11-W, Xam3-W and Xam27-C) (Figure 4) obtained from Coast, eastern and western regions of Kenya. Isolates in this sub-cluster were characterized by small, white, circular, smooth, mucoid translucent and elevated colonies. Subcluster II comprised of fifteen isolates (Xam22-N, Xam31-C, Xam1-W, Xam8-W, Xam5-W, Xam30-C, Xam29-C, Xam21-N, Xam24-N, Xam25-C, Xam23-N, Xam7-W, Xam33-C and Xam32C) (Figure 4) obtained from Coast, Nyanza and western regions. Isolates in this sub-cluster were characterized by small, white, circular, smooth, moist and translucent colonies. The Xam isolates from the different geographical regions were randomly clustered. Differences in morphological characteristics have also been reported by McGuire and Jones [25] and Willems et al. [27].

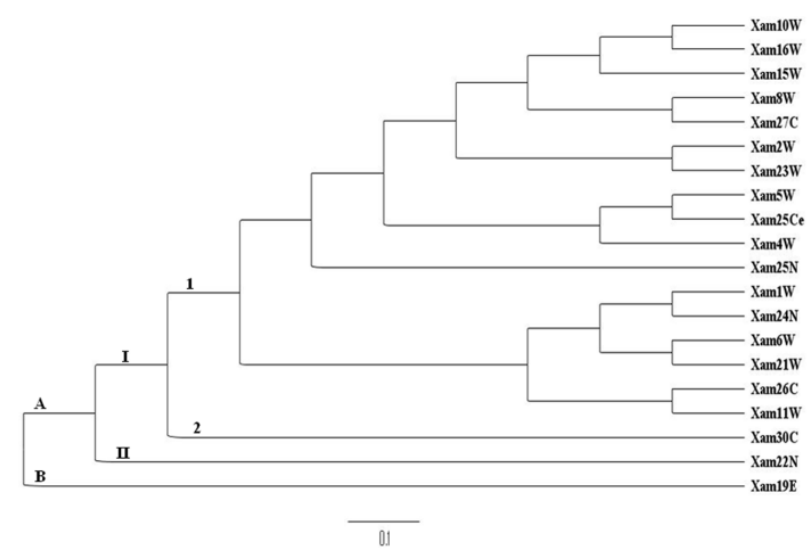

Fig. 4: Dendrogram of phenotypic diversity of $26 \mathrm{Xam}$ isolates generated using morphological characteristics.

\subsection{PCR analysis of Xam isolates}

To confirm the microbiological and biochemical identification, 19 Kenyan Xam isolates were further tested by PCR. The PCR amplification of total genomic DNA was based on Xam-specific primers XK-XV. The primer pair XV-XK successfully amplified the expected $898 \mathrm{bp}$ fragment of the bacterium DNA of all the 19 isolates.

\subsection{Genetic diversity of $\mathrm{Xam}$ isolates by rep-PCR genomic fingerprinting}

PCR-based approaches have been used to study genetic diversity of phytopathogenic bacteria and generate evidence of their ecological distribution and evolution [28, 29]. In this study, the genetic diversity within Kenyan Xam population was assessed using rep-PCR method.

All isolates produced characteristic fingerprint pattern with bands ranging between 300 and $3000 \mathrm{bp}$ and their numbers ranged from 1 to 6 bands per isolate (Figure 5). The same fingerprints were observed when the PCR was repeated at least three times, demonstrating the reproducibility of this technique for 
genetic studies of Xam. Some minor light amplification bands were also not reproducible, suggesting non-specific binding and such bands were not taken into account. This is in agreement with previous studies by Janssen et al. [30] and Restrepo et al. [32] who confirmed the usefulness of rep-PCR in characterizing bacterial populations and its applicability to the study of Xam populations.

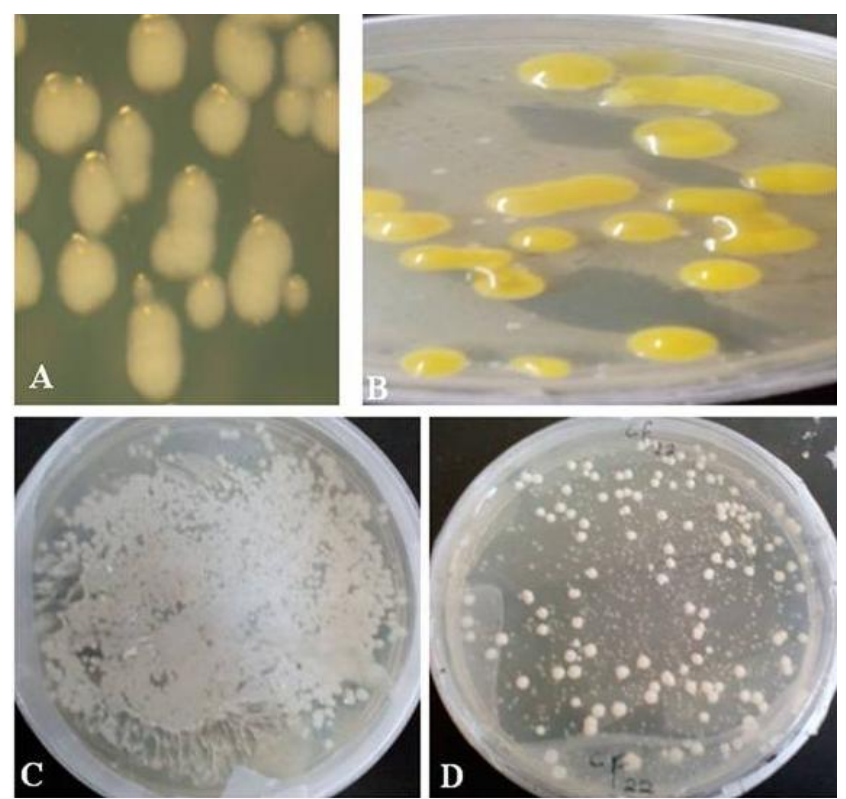

Fig. 5: Agarose gel electrophoresis of rep-PCR fingerprinting patterns from genomic DNA of Xam isolates obtained from infected cassava. Lanes M represent $1 \mathrm{~kb}$ molecular weight marker (Fermentas); Lanes 1 (Xam1-W), 2 (Xam24-N), 3 (Xam19-E), 4 (Xam26-C), 5 (Xam8-W), 6 (Xam6-W), 7 (Xam2-W), 8 (Xam22-N), 9 (Xam27-C), 10 (Xam30-C), 11 (Xam20-N), 12 (Xam16-W), 13 (Xam16-W), 14 (Xam5-W), 15 (Xam21-N), 16 (Xam23-N), 17 (Xam4-W), 18 (Xam11-W) and 19 (Xam25-Ce) represent Xam isolates from Western (W), Nyanza (N), Coast (C), Eastern (E) and Central (Ce) regions of Kenya.

Majority of isolates revealed complex banding pattern, with only four isolates exhibiting less than four bands. Isolates Xam19-E and Xam24-N generated a low complexity pattern with one and three bands, respectively. Although a lower number of clearly scorable bands were observed in some isolates (Figure 5), the three repeats of rep-PCR amplifications revealed that the absent bands are reproducible. The findings from the present study are in agreement with reports by Restrepo et al. [33] demonstrating the high discriminatory power of rep-PCR when characterizing Xam populations with low levels of genetic diversity in Colombia.

To examine the relatedness of Kenyan Xam populations, rep-PCR fingerprints for selected 19 isolates were used to construct a dendrogram based on the similarity in the polymorphisms of the DNA fragments generated. Overall, limited genetic variability was observed among most of the assessed Xam populations in Kenya, with the exception of isolate Xam-19E that appeared to differ from the rest of the isolates (Figure 6). At 10\% similarity coefficient level, isolate Xam-19E that had unique gel fingerprints (only single band) clustered alone while the rest of isolates randomly clustered in one cluster. These finding confirms the existence of limited genetic diversity within the current populations of Xam in Kenya. The UPGMA analysis generated random clusters regardless of the geographical origin of the isolates (Figure 4).

For example, isolate Xam-11W from Vihiga County in Western region clustered together with isolate Xam-26C from Kilifi County in coastal Kenya. Isolate Xam-5W (from Kakamega County in western Kenya) clustered with isolate Xam-25Ce (from Kiambu County in central Kenya) (Figure 6). High genetic similarity coefficients were recorded for Xam isolates from Western and Coastal regions (Table 2) and hence high genetic homogeneity.

The genetic similarities observed among Kenyan strains isolated in different geographical locations (Western, Nyanza, Coast, Eastern and Central), demonstrate a clonal population structure for the pathogen. The lack of correlation between repPCR groupings and geographic origin of isolates is an indication that this bacterium has spread among different regions in Kenya. The results suggest that these isolates have not as yet diversified at the chromosomal level. The genetic diversity could not differentiate the yellow strain from the white and cream strains that cause cassava bacterial blight disease.

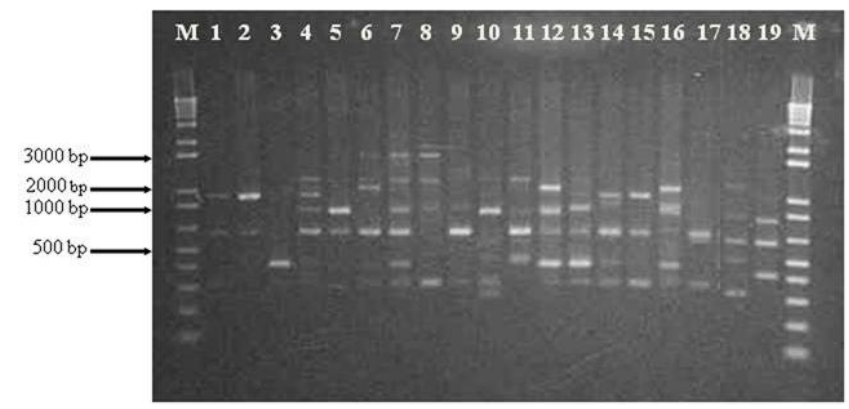

Fig. 6: Unweighted pair group method, arithmetic average (UPGMA) dendrogram constructed from rep-PCR fingerprinting data of Xam isolates from different regions in Kenya.

The random clustering of the Xam isolates from different geographical regions could be due to the continuity of the main cassava growing regions in Kenya. It is possible that a single isolate was introduced in Kenya and simultaneously spread to other parts.

Moreover, the farmer practice of obtaining plant materials from near and far, without taking precautions to avoid carrying infected stem cuttings and moving that to another place over a long distance could have perpetuated the same isolate. However, the exact source of the prevailing epidemic in Kenya still remains unknown. These results contradicts studies from other countries such as Columbia by Restrepo et al. [32] who reported that Xam causing bacterial blight exhibit a high level of genotypic variability and geographical differentiation. 
Table 2: Similarity matrix of Xam isolates based on combined analysis of Jaccard matrix

\begin{tabular}{|c|c|c|c|c|c|c|c|c|c|c|c|c|c|c|c|c|c|c|c|c|}
\hline & $\underset{\nexists}{\Xi}$ & 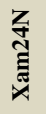 & 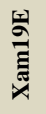 & 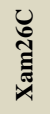 & 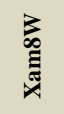 & 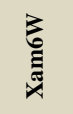 & 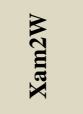 & $\underset{\text { Z }}{\text { Z }}$ & 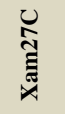 & 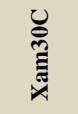 & 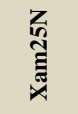 & 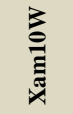 & $\frac{3}{\bar{E}}$ & 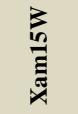 & 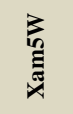 & 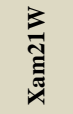 & 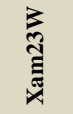 & 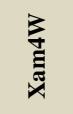 & 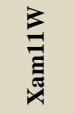 & 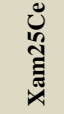 \\
\hline Xam1W & 1 & 1 & 0 & 0.5 & 0.25 & 0.5 & 0.143 & 0 & 0.25 & 0 & 0.25 & 0.2 & 0.2 & 0.2 & 0.5 & 0.667 & 0.167 & 0.333 & 0.4 & 0.25 \\
\hline $\mathrm{Xam} 24 \mathrm{~N}$ & & 1 & 0 & 0.5 & 0.25 & 0.5 & 0.143 & 0 & 0.25 & 0 & 0.25 & 0.2 & 0.2 & 0.2 & 0.5 & 0.667 & 0.167 & 0.333 & 0.4 & 0.25 \\
\hline Xam19E & & & 1 & 0 & 0 & 0 & 0.167 & 0 & 0 & 0 & 0.333 & 0.25 & 0.25 & 0.25 & 0.25 & 0 & 0.2 & 0 & 0.2 & 0.333 \\
\hline Xam26C & & & & 1 & 0.4 & 0.333 & 0.429 & 0.167 & 0.4 & 0.167 & 0.4 & 0.333 & 0.333 & 0.333 & 0.333 & 0.4 & 0.5 & 0.2 & 0.5 & 0.167 \\
\hline Xam8W & & & & & 1 & 0.4 & 0.5 & 0.2 & 1 & 0.5 & 0.2 & 0.75 & 0.75 & 0.75 & 0.4 & 0.5 & 0.6 & 0.667 & 0.333 & 0.5 \\
\hline Xam6W & & & & & & 1 & 0.429 & 0.4 & 0.4 & 0.167 & 0.167 & 0.333 & 0.333 & 0.333 & 0.6 & 0.75 & 0.286 & 0.5 & 0.286 & 0.4 \\
\hline Xam2W & & & & & & & 1 & 0.5 & 0.5 & 0.286 & 0.5 & 0.667 & 0.667 & 0.667 & 0.429 & 0.286 & 0.833 & 0.333 & 0.375 & 0.5 \\
\hline Xam22N & & & & & & & & 1 & 0.2 & 0.2 & 0.2 & 0.167 & 0.167 & 0.167 & 0.167 & 0.2 & 0.333 & 0.25 & 0 & 0.2 \\
\hline Xam27C & & & & & & & & & 1 & 0.5 & 0.2 & 0.75 & 0.75 & 0.75 & 0.4 & 0.5 & 0.6 & 0.667 & 0.333 & 0.5 \\
\hline Xam30C & & & & & & & & & & 1 & 0 & 0.4 & 0.4 & 0.4 & 0.167 & 0.2 & 0.333 & 0.25 & 0.333 & 0.2 \\
\hline $\mathrm{Xam} 25 \mathrm{~N}$ & & & & & & & & & & & 1 & 0.4 & 0.4 & 0.4 & 0.4 & 0.2 & 0.6 & 0.25 & 0.333 & 0.5 \\
\hline Xam10W & & & & & & & & & & & & 1 & 1 & 1 & 0.6 & 0.4 & 0.8 & 0.5 & 0.5 & 0.75 \\
\hline Xam16W & & & & & & & & & & & & & 1 & 1 & 0.6 & 0.4 & 0.8 & 0.5 & 0.5 & 0.75 \\
\hline Xam15W & & & & & & & & & & & & & & 1 & 0.6 & 0.4 & 0.8 & 0.5 & 0.5 & 0.75 \\
\hline Xam5W & & & & & & & & & & & & & & & 1 & 0.75 & 0.5 & 0.5 & 0.5 & 0.75 \\
\hline Xam21W & & & & & & & & & & & & & & & & 1 & 0.333 & 0.667 & 0.333 & 0.5 \\
\hline Xam23W & & & & & & & & & & & & & & & & & 1 & 0.4 & 0.429 & 0.6 \\
\hline Xam4W & & & & & & & & & & & & & & & & & & 1 & 0.167 & 0.667 \\
\hline Xam11W & & & & & & & & & & & & & & & & & & & 1 & 0.333 \\
\hline Xam25Ce & & & & & & & & & & & & & & & & & & & & 1 \\
\hline
\end{tabular}

\section{CONCLUSION}

In conclusion, the results of this study demonstrate that Xam is widespread in all cassava growing regions of Kenya. The presence of this pathogen in the different cassava growing regions of Kenya should be considered as significant threat to food security particularly among the subsistence and smallholder cassava farmers. Analyses done using rep-PCR reported here provides the first data on the molecular characteristics of Xam infecting cassava in Kenya, and perhaps not yet reported in other parts of the world. The results also demonstrated a very high genetic relatedness within Xam isolates that were isolated on cassava from Kenya. From this, one can speculate that the current Xam populations in Kenya have evolved from the same origin, and this, may prove useful in future breeding programmes. Additionally, the high genetic homogeneity indicates that development and wide use of a single resistant variety will effectively control the disease.

\section{ACKNOWLEDGEMENTS}

The authors would like to thank Dr. Evans Nyaboga for providing reagents for this work and also the Department of Biochemistry, University of Nairobi, for providing the laboratory facilities. We are also grateful to Samuel Mwaura for assistance during sample collection.

\section{Financial support and sponsorship: Nil.}

Conflict of Interests: There are no conflicts of interest.

\section{REFERENCES}

1. FAO. FAOSTAT statistical database, agriculture data. 2013. Available online at: http://apps.fao.org.

2. Verdier V, Restrepo S, Mosquera G, Jorge V, Lopez C. Recent progress in the characterization of molecular determinants in the Xanthomonas axonopodis pv. manihotis-cassava interaction. Plant Molecular Biology. 2004; 56(4): 573-584.
3. Ogunjobi AA. Molecular variation in population structure of Xanthomonas axonopodis pv. manihotis in the south eastern Nigeria. African Journal of Biotechnology. 2006; 5(20): 1868-1872.

4. Jorge V, Fregene M, Vélez CM, Duque MC, Tohme J, Verdier V. QTL analysis of field resistance to Xanthomonas axonopodis pv. manihotis in cassava. Theoretical and Applied Genetics. 2001; 102(4): 564-571.

5. Restrepo S, Duque MC, Verdier V. Characterization of pathotypes among isolates of Xanthomonas axonopodis pv. manihotis in Colombia. Plant Pathology. 2000; 49(6): 680-687.

6. Lozano JC. Cassava bacterial blight: a manageable disease. Plant Disease. 1986; 70: 1089-1093.

7. McDonald BA, Linde C. The population genetics of plant pathogens and breeding strategies for durable resistance. Euphytica. 2002; 124 : 163-180.

8. Dixon AG, Ngeve JM, Nukenine EN. Genotype $\times$ environment effects on severity of cassava bacterial blight disease caused by Xanthomonas axonopodis pv. manihotis. European Journal of Plant Pathology. 2002; 108(8): 763-770.

9. Ma XL, Kong P, You MP, Li H, Sivasithamparam K, Barbetti MJ. Molecular variation among isolates belonging to eight races of Phytophthora clandestina. Australasian Plant Pathology. 2009; 38: 608-616.

10. Miesfeld RL. Rapid amplification of DNA. In Applied Molecular Genetics. A John Wiley \& Sons, INC Publication; 1999.

11. Verdier V, Boher B, Maraite H, Verdier V, Geiger J. Pathological and molecular characterization of Xanthomonas campestris strains causing diseases of cassava (Manihot esculenta). Applied and Environmental Microbiology. 1994; 60(12): 4478-4486.

12. Restrepo $\mathrm{S}$ and Verdier V. Geographical Differentiation of the Population of Xanthomonas axonopodis pv. manihotis in Colombia. Applied and Environmental Microbiology, 1997. 63(11): 4427-4434.

13. Louws FJ, Fulbright DW, Stephens CT, de Bruijn FJ. Specific genomic fingerprints of phytopathogenic Xanthomonas and Pseudomonas pathovars and strains generated with repetitive sequences and PCR. Applied and Environmental Microbiology. 1994; 60(7): 2286-2295.

14. Cruz CV, Ardales EY, Skinner DZ, Talag J, Nelson RJ, Louws FJ, Leach JE. Measurement of haplotypic variation in Xanthomonas oryzae pv. oryzae within a single field by rep-PCR and RFLP analyses. Studies. 1996; 15: 18.

15. Cubero J, Graham JH. Genetic relationship among worldwide strains of Xanthomonas causing canker in citrus species and design of new 
primers for their identification by PCR. Applied and Environmental Microbiology. 2002; 68(3): 1257-1264.

16. Verdier V, Mosquera G, Assigbétsé K. Detection of the cassava bacterial blight pathogen, Xanthomonas axonopodis pv. manihotis, by polymerase chain reaction. Plant Disease. 1998. 82(1): 79-83.

17. Ogunjobi AA, Fagade OE, Dixon AGO. Physiological studies on Xanthomonas axonopodis pv. manihotis (Xam) strains isolated in Nigeria. Advances in Biological Research. 2008; 2(5-6): 90-96.

18. Bradbury JF. Identification and characteristics of Xanthomonas manihotis. In Terry, ER; Persley, GJ; Cook, SCA (edxs.). Workshop on cassava bacterial blight in Africa, Past, Present and Future (1978, Ibadan, Nigeria). Report. 1978.

19. Gregersen T. Rapid method for distinction of Gram-negative from Gram-positive bacteria. European Journal of Applied Microbiology and Biotechnology. 1978; 5(2): 123-127.

20. Bradbury JF. Identification et Caractéristiques de Xanthomonas manihotis. In: Terry, E.R., Persley, G.J. and Cook, S.C.A., Eds., La Bactériose du Manioc en Afrique: Le Passé, le Présent, L'avenir: Compte Rendu du Séminaire Interdisciplinaire Qui S'est Tenu à L'IITA, Ibadan, Nigéria, du 26 Au 30 Juin 1978, Parrainé Par le Centre de Recherche Pour le Developpement International, Ottawa, Canada, et L'Institut International D'agriculture Tropicale, Ibadan, Nigeria, Natural Resources Institute, 1979; p. 1-4..

21. Fahy PC, and Persley GJ. Plant bacterial diseases. A diagnostic guide. Academic Press Australia; 1983.

22. Louws FJ, Bell J, Medina-Mora CM, Smart CD, Opgenorth D, Ishimaru CA, Fulbright DW. rep-PCR-mediated genomic fingerprinting: a rapid and effective method to identify Clavibacter michiganensis. Phytopathology. 1998; 88(8): 862-868.

23. Verdier V, Restrepo S, Mosquera G, Jorge V, Lopez C. Recent progress in the characterization of molecular determinants in the Xanthomonas axonopodis pv. manihotis-cassava interaction. Plant Molecular Biology. 2004. 56(4): 573-584.

24. Trujillo CA, Ochoa JC, Mideros MF, Restrepo S, López C, Bernal A. A complex population structure of the cassava pathogen Xanthomonas axonopodis pv. manihotis in recent years in the Caribbean Region of Colombia. Microbial Ecology. 2014; 68(1): 155-167.

25. McGuire RG. and Jones JB. Recovery of Xanthomonas campestris pv. vesicatoria from tomato seed. Plant In: Pathogenic Bacteria, Current Plant Science and Biotechnology in Agriculture, Springer. 1987, p. 768

26. Rodriguez S, Stapleton JJ, Civerolo EL. Xanthomonas campestris involved in Mexican lime bacteriosis in Colima, Mexico. In: Pathogenic Bacteria, Current Plant Science and Biotechnology in Agriculture, Springer 1987, p. 658-662.
27. Willems A, Gillis M, Kersters K, Van Den Broecke L, De Ley J. Transfer of Xanthomonas ampelina Panagopoulos 1969 to a New Genus, Xylophilus gen. nov., as Xylophilus ampelinus. (Panagopoulos 1969) comb. nov. Internal Journal of Systemic Bacteriology. 1987; 37(4): 422-430.

28. Adhikari TB, Mew TW, Leach JE. Genotypic and phenotypic diversity in Xanthomonas oryzae pv. oryzae in Nepal. Phytopathology. 1999; 89: 687-694.

29. Kumar A, Sarma YR, Anandaraj M. Evaluation of genetic diversity of Ralstonia solanacearum causing bacterial wilt of ginger using REP-PCR and PCR-RFLP. Current Science. 2004; 87: 1555-1561.

30. Janssen P, Coopman R, Huys G, Swings J, Bleeker M, Vos P, Kersters K. Evaluation of the DNA fingerprinting method AFLP as a new tool in bacterial taxonomy. Microbiology. 1996; 142(7): 18811893.

31. Restrepo S, Velez CM, Verdier V. Measuring the genetic diversity of Xanthomonas axonopodis pv. manihotis within different fields in Colombia. Phytopathology. 2000; 90: 683-690.

32. Restrepo S, Verdier V. Geographical differentiation of the population of Xanthomonas axonopodis pv. manihotis in Colombia. Applied and Environmental Microbiology. 1997; 63(11): 4427-4434.

33. Restrepo S, Velez M, Duque C, Verdier V. Genetic structure and population dynamics of Xanthomonas axonopodis pv. Manihotis in Colombia from 1995 to 1999. Applied and Environmental Microbiology. 2004; 70(1): 255-261.

\section{How to cite this article:}

Chege MN, Wamunyokoli F, Kamau J, Nyaboga EN. Phenotypic and genotypic diversity of Xanthomonas axonopodis pv. manihotis causing bacterial blight disease of cassava in Kenya. J App Biol Biotech. 2017; 5 (02): 038-044. 